\title{
tie
}

\section{MEASURING REGULATORY INTENSITY \\ BY THE SPANISH REGIONS (1978-2009) ${ }^{1}$}
IE Business School Working Paper
DE8-132-I
$11 / 11 / 2010$

\author{
FRANCISCO MARCOS ${ }^{2}$ \\ JUAN SANTALÓ 3 \\ ALBERT SÁNCHEZ-GRAELLS ${ }^{4}$
}

\begin{abstract}
This paper constructs several objective indicators of regulatory intensity in the context of the Spanish decentralization since 1978. Our aim is to develop a quantitative measure of the levels of regulatory intensity set by different regions in Spain. The dynamic nature of the decentralization process requires that we take into account the initial institutional framework for decentralization and the successive transfers of powers to the regions. As a result, we obtain a series of variables that measure regulatory intensity across Spanish regions in the period 1978-2009.
\end{abstract}

Keywords: Regulation, Regulatory Intensity, Decentralisation, Spain, Selfgoverning Communities, Regions, Federalism.

Jel Codes: K20, K40

\footnotetext{
${ }_{1}^{1}$ This paper is part of a broader project that tries to assess the impact of disparate regulation by Spanish Self Governing Communities (SGCs) on productivity and innovation (see MARCOS \& SANTALÓ 2010). A preliminary study was presented under the title "Decentralization, Regulatory Burden and Economic Development in Spain" at the 24th Annual Conference of the European Association of Law and Economics, celebrated at Copenhagen Business School in September 2007 (available at http://ssrn.com/abstract=948457, visited 22.10.2010) and at a Workshop Organized by the Spanish Association of Law and Economics at Universidad Complutense de Madrid in June 2008. The criticisms and suggestions by the attendants to those meetings are hereby gratefully acknowledged. We also acknowledge the comments of two anonymous referees. The authors are thankful for the financial support of the European Network for Better regulation and Spanish Ministry of Education's research grant \#SEJ2007-67582-C02-01.

2 Professor of Law, IE Law School, Serrano 118, Madrid, E-28006 Spain.

3 Professor of Strategy, IE Business School, María de Molina 12, Madrid, E-28006 Spain.

${ }^{4}$ Lecturer in Commercial Law, Pontifical University Comillas - ICADE, Alberto Aguilera, 23, Madrid, E-28015 Spain.
} 
Copyright (C) 2010 by Francisco Marcos, Juan Santaló, Albert Sánchez-Graells.

This working paper is distributed for purposes of comment and discussion only. It may not be reproduced without permission of the copyright holders. Copies of working papers are available from the authors.

Printed at IE Business School, Madrid, Spain. Please, do not reproduce or circulate without permission. 


\section{INTRODUCTION.}

There is substantial academic literature on the measurement and analysis of regulation. Most of the studies focus on particular types of regulation, normally industry-specific, and only look at the limited reality in which those rules and their enforcement produce effects [see the surveys by Joskow \& ROSE (1989) and Joskow \& NOLL (1981) and see also KAHN (1988)].

There is also a stream of literature that analyzes public regulation in general terms, as the set of rules and supporting institutions that establish the conditions for business organizations to operate and market transactions to take place [see OGus (1994:15-75)].

Some of the studies on general regulation and rules have built regulatory indicators that are used cross-country to compare governance and regulatory outcomes in different countries ${ }^{1}$. On top of their academic interest, governments and international organizations use them as a relevant tool for policy and regulation reform.

Most regulatory measures try to capture the quality and enforcement of regulatory rules but they face several difficulties in creating and shaping an objective and comprehensive indicator. They generally introduce initial assumptions or preconceptions that require some subjective assessment or judgment. Objective and subjective measures can be distinguished ${ }^{2}$, since shaping and framing risks involuntarily introducing subtle ideological biases.

The subjective prejudice is clear in surveys, since it is very difficult to avoid any bias in framing and formulating the questions included in the survey and choosing the respondents and sample size [PRYOR (2002: 706)]. Surely, some surveys are organized in a way that provide respondents no leeway for introducing their subjective valuations and opinions ${ }^{3}$, but the questions asked may easily and involuntarily be biased. Although less prevalent, other indicators

\footnotetext{
${ }^{1}$ On the limitations of these indicators, see RosentHAL \& VOETEN (2007).

${ }^{2}$ WOODRUFF (2006: 107). Of course, subjective indicators (mainly surveys) are always required when they try to capture informality (id. 121).

${ }^{3}$ WoODRUFF (2006:109) refers to World Bank's Doing Business surveys as one trying to follow this methodology. On the other hand, CONWAY, JANOD Y NICOLETTI (2005: 3, 9) consider PMR indicators of the OECD International regulation database to be objective, but they neglect that it introduces subjective measures in the choice of relevant regulatory elements and weight assignment to each of them.
} 
that code different features of law and governmental regulations may also introduce preliminary subjective valuations ${ }^{4}$. Indeed, although they may be based on objective data, they will occasionally fall in a subjective bias when they choose test cases and simulations that provide the spinal cord of the indicator.

For that reason, we aim at building a purely objective measure of regulation adopted by Spanish Self Governing Communities (hereinafter SGCs), in which no prior inference or deduction is made from crude data ${ }^{5}$. Our intent is to develop an indicator that measures regulatory intensity, not regulatory quality, and that allows us to determine comparatively how far do SGCs go in exercising their legislative and regulatory powers.

On the other hand, objective measures normally have the disadvantage of being unable to look at regulation enforcement and effectiveness [NICOLETTI \& PRYOR (2006: 435)]. It is one thing to look at the rules or regulations in paper ('law on the books'), and another one to look at whether and how they are being enforced or implemented [PRYOR (2002: 697-698)].

Being it complex to calculate regulatory intensity, it is even more difficult to assess and measure 'law in action' without making any kind of subjective valuation. Measuring law abidance and enforcement normally involves detailed analysis of administrative decisions, court opinions and other quality measures of compliance and of the legal environment in which activities take place. However, as we will see later on, we aim also at including an objective proxy of effectiveness or enforcement intensity in our measurement of SGC variations.

\footnotetext{
${ }^{4}$ Nevertheless, in our opinion some of the indicators considered objective may suffer some subjectivity in their construction, see NICOLETTI \& PRYOR (2006: 435). This may be of no much importance as they show how the subjective and objective measures are strongly and statistically correlated in their results despite also differences in coverage or scope of indicators (id. 444: "Both the objective and subjective measures seem to reflect the same reality").

${ }^{5}$ That will fulfill a strict objectivity test, see VOIGT (2009:19): "«Objetivity» in measurement implies that anybody repeating the identical measurement exercise should end up with exactly the same results". In their analysis of regulatory intensity in Spain, GUAL ET AL (2006: 30-32) and ZARATÉ \& VALLES (2010) use the number of rules adopted by SGCs but later on make a further distinction among them according to the subject matter of regulation which already requires some kind subjective assessment. A regulation or rule-count exercise is undoubtedly objective [and we will make our own later (see infra § 4)] but it does not tell you anything about the content of the rule, which can be better approached with a page-count exercise.
} 


\section{Developing an Objective Measure of Regulatory Intensity.}

It is difficult to establish an objective and accurate measure of regulatory intensity, but the Spanish decentralized State provides a unique ground for shaping an indicator that captures the variations in their exercise of legislative and regulatory powers and allows making comparisons ${ }^{6}$. As we will explain later (see infra § 3), Spanish SGC provide an excellent setting to measure different strategies on regulatory intensity and effectiveness and enforcement intensity by SGC.

We will look at an indirect and rough objective indicator of regulatory intensity: the number of pages published in the official journals. They will be used as the indication of the proneness of SGC to introduce new regulations and enforce them ${ }^{7}$. This idea is not new. Milton Friedman was the first one to use the number of pages in the Federal Register (Fed. Reg.) as a proxy for US federal regulatory activity, pointing out how during President Nixon's mandate the number of pages of the Register doubled, whilst it halved during Reagan's Presidency (see table in next page). Friedman was conscious that the Register was an imperfect measure, but illustrative nevertheless ${ }^{8}$.

\footnotetext{
${ }^{6}$ In this paper, aside from developing the methodology, describing the variables and providing the rough empirical results we do not purport to further elaborate on them and, for example, look at their relationship with other relevant regional measures and data (such as SGCs' budgets, SGCs' governing political parties, etc.), which may lead to interesting conclusions. See, however MARCOS \& SANTALÓ (2010). Neither are we trying to construct an (isolated) SGC regulatory ranking, as we doubt the usefulness of this exercise and the distorted portrait of reality it might give. However, those interested in a ranking of SGCs that looks at different dimensions of regional policy and activity, see CABRILLO (2008).

${ }^{7}$ DAWSON \& SEATER (2007: 7-8) describe it as a "completely objective" method. GoFF (1996: 2429) uses it and the United States Code Annotated (USCA) as a component of the Effective Regulatory Index (ERI) he constructs in his book.

8 The Fed. Reg. is published daily (it can be downloaded from http://www.gpoaccess.gov/fr/index.html, visited 22.10.2010). It is the main source for U.S. federal government agency proposed and final rules, notices of meetings and adjudicatory proceedings (final rules published in the Register will ultimately become part of the Code of Federal Regulations).

It is true that it does not publish all the laws and regulation, but only administrative rules ("They are not laws and yet they have the effect of laws and like laws impose costs and restrain activities") and also that it publishes more than solely rules affecting business and economic activity, but he considered it as a valid proxy for regulatory activity.
} 
Figure 2

Number of Pages Added to the Federal Register Each Year, 1960-1999

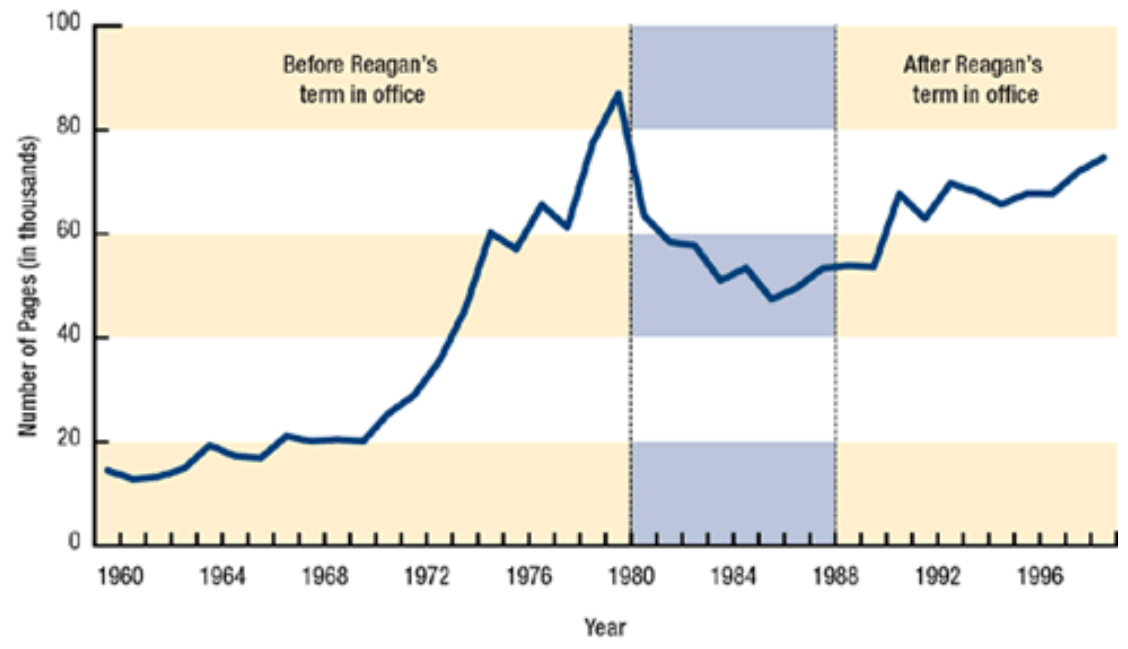

Source: http://www.hooverdigest.org/043/friedman.html (extracted from Milton Friedman, "Freedom's Friend", Wall Street Journal, 11 june 2004, A8,visited 22.10.2010).

Using the number pages in Regional Official Journals as an indicator of regulatory intensity is intuitively appealing ${ }^{9}$. The enactment process of laws and regulation requires their prior publication as a condition of their effectiveness. It does so to provide those subject to the legal and regulatory rules the possibility of learning and knowing that a new rule is in force. This is a major principle of the rule of law ${ }^{10}$. Technically, Official Journals are not source of law themselves but they act as a necessary publicity instrument, to diffuse knowledge of laws ${ }^{11}$.

Regulatory intensity is a good proxy for the regulatory burden on business. Indeed, firms and their advisors look at Official Journals of the jurisdictions in which they operate as one of the instruments to know the applicable rules, and

\footnotetext{
9 In fact, recent studies on global taxation have used the number of pages of primary tax legislation as the proxy for tax regulatory burden, such as PRICEWATERHOUSECOOPERS-WORLD BANK (2006: 17-18). In Spain, number of pages in official journals has been used to graphically show the regulatory burden introduced by the State (not looking at SGCs) and even by the EU, See VALLÉS \& ZARATE (2006: 218 \& 220) and ROSELL (2006:8-9).

${ }^{10}$ The publicity of norms is one of the principles over which the State and the Bill of Rights is built in the Spanish Constitution (section 9.3). See legal arguments 2 and 3, Constitutional Court Judgment 179/1989, of 2 November (BOE 290, 4 December 1989)

${ }^{11}$ Article 2 of Spanish Civil code sets this requirement for the effectiveness and applications of norms. Section 91 of the Spanish Constitution introduces the publication requirement for State laws whilst section 24.4 of the Law of Government (50/1997, of 27 de November) does it for State regulations. The same requirements are established for SGC's laws and regulations in their respective Statutes of Autonomy.
} 
-therefore- it is plausible to relate the length of the official journal with the burden imposed by rules $^{12}$. Furthermore, the compliance costs that firms incur are directly related to the quantity or amount of legislation and regulation adopted.

Of course, like Milton Friedman, we are conscious that some of the Official journals' pages will not relate to regulatory burden over business activities, as things different to rules are published in the Official journals (procurement notices, announcements). Besides, some of the rules are of organizational character and concern administrative bureaucracy, the organization of State and State bodies, nevertheless we think these are also regulatory activities that may have an indirect impact on business environment. Therefore, we have to bear in mind that part of the content of the Official journal cannot be strictly considered of normative or regulatory relevance -because it is not formally legislation or any other form of direct regulatory activity- but, at the same time, we deem that even published changes in the organisation of public administration, judicial announcements or other notices impose direct and indirect costs on businesses. On the one hand, the bigger the volume of the Official journal, the larger the information costs associated to its review. On the other hand, administrative and judicial activity in most cases involve private

\footnotetext{
${ }^{12}$ A similar quantitative methodology (leximetrics) is used by COOTER \& GINSBURG (2004), who count the number of words in a legal document to systematically compare differences in legal specificity across countries (in the transposition of EU Directives) after normalizing the differences for linguistic variations, explaining them by agency problems between drafters and interpreters of legal instruments. Although the same terminology is used in other recent numerical comparative corporate law studies -LELE \& SIEMS (2007) and SIEMS (2008)-, in the end their measurement exercise is based in the (qualitative and subjective) choice, use and analysis of variables, weighting and coding for shareholder protection in comparing legal systems.
}

Other studies have used objective data as the length (words/pages) and footnoting judicial opinions as an indicative of changes in the law and enforcement patterns [see SCHUCK \& ELLIOT 1990: 1003-1004; regarding the influence of Chevron U.S.A., Inc. V. NRDC, 467 U.S. 837 (1984) in the review of administrative decisions by courts]. LANDES \& POSNER (2004: 2-5) consider the changes in the length (measured by words) of the Copyright, Trademark and Patent Acts as an indication of the correlative expansion of intellectual property rights and the growth in Intellectual Property Protection. Finally, BLACK \& SPRIGS II (2010) try to find out the determinants of the length (words) of 27.615 majority opinions of the U.S. Supreme Court from 1791-2005 (considering law clerks' involvement, Justices interaction, case importance or unimportance, etc).

In Spain, SANTA MARíA PASTOR (2004: 386388) uses the length (pages and characters) of laws and regulations as an indication of an over-regulation trend by public powers and the increasing complexity of the Spanish legal system (he also compared the amount of characters employed in laws and regulations with those superseded). 
companies' interests and, therefore, publications related to public administration and judiciary activities are also an indicator of the indirect compliance costs that business firms face ${ }^{13}$.

\section{The Spanish decentralisation.}

The Spanish decentralization since 1978 provides a natural setting in which we can shape an indicator of regional regulatory intensity. Before we do that, we need to delve briefly on the framework and characteristics of the regional organization of Spain after the adoption of the current Constitution in 1978.

After the fall of the totalitarian regime of General Francisco Franco, Spain recovered political freedom and the Spanish Constitution of 1978 (hereinafter, the "Constitution") ${ }^{14}$ created a new institutional framework for the organization of the State. The Constitution allows for a flexible model of decentralised State but establishes an absolute (although vague) limit by clearly stating: "under no circumstances shall a federation of Self-governing Communities be allowed" (section 145) ${ }^{15}$.

Therefore, the Constitution allows for a decentralised, although not federal, structure of the State. The final configuration of this "State of the Autonomies" has resulted in the Spanish territory being divided in seventeen Self-governing Communities (hereinafter, the "SGC") ${ }^{16}$, created in the first few

\footnotetext{
${ }^{13}$ However, the construction of an enforcement indicator that captures regional variations in law and regulation enforcement would be misleading as regional and local regulation are frequently enforced together and at the same time with national ones and there is not feasible way to isolate them.

${ }^{14}$ A full-text official English translation of the Spanish Constitution of December 1978 is available at http://www.congreso.es/ingles/funciones/constitucion/const espa texto.pdf, visited 22.10.2010.

${ }^{15}$ The Constitution declared the new political system to be "based on the indissoluble unity of the Spanish Nation, the common and indivisible homeland of all Spaniards; it recognizes and guarantees the right to self-government of the nationalities and regions of which it is composed and the solidarity among them all" (section 2). More precisely, the Constitution establishes that "in the exercise of the right to self-government recognised in section 2 of the Constitution, bordering provinces with common historic, cultural and economic characteristics, insular territories and provinces with a historic regional status may accede to self-government and form Self-governing Communities (Comunidades Autónomas)" (section 143.1).

${ }^{16}$ These are: Galicia, Cantabria, Asturias, País Vasco, La Rioja, Navarra, Aragón, Cataluña, Extremadura, Castilla y León, Madrid, Castilla - La Mancha, Valencia, Baleares, Murcia, Andalucía and Canarias. Moreover, there are two Self-governing cities in the north-African territories of Ceuta and Melilla.
} 
years after the enactment of the Constitution. Some of the SGC inherited the tradition of certain historic territories (Catalonia, Galicia and the Basque Country) whilst the rest of the territorial divisions were mainly based on geographic criteria.

The decentralization process in Spain was aimed at transferring powers and powers from the State to smaller entities of regional base -the SGC- and it was inspired not only on economic reasons, but also on political and historical grounds (PÉREZ DíAZ, 1993). Indeed, decentralisation began in 1978 as a reaction to the strong centralism of the Franco regime. However, like in federal States, theoretically it was not to take place in those policies and areas in which different reasons advice for a uniform or homogeneous design across the entire State.

\subsection{Decentralisation Framework: Principles and Limits.}

According to the Constitution, a second-tier constitutional document called Statute of Autonomy shall "be the basic institutional rule of each Self-governing Community and the State shall recognize and protect them as an integral part of its legal system" (section 147.1). Most noteworthy for our purposes, the Statutes of Autonomy shall regulate "the powers assumed [by the SGC] within the framework laid down by the Constitution and the basic rules for the transfer of the corresponding services" (section 147.2.d). The Constitution also draws a distinction between the powers that can be assumed by the SGC (section 148) and those that will in any case lie on the Central Government (section 149) ${ }^{17}$.

\footnotetext{
17 Annex 1 reproduces both sections as the constitutional framework for the distribution of competencies between the Central Government and the Self-governing Communities, and lists the Laws approving the seventeen Statutes of Autonomy. A comparative description of the seventeen Statutes of Autonomy is available (in Spanish) at http://www.mpt.es/documentacion /politica autonomica/Estatutos Autonomia/estatutos materias/parrafo/016/document es/16Competencias nuevo 05 b.pdf (visited 22.10.2010)

As a closing rule, and trying to avoid any gaps in the distribution of powers, the Constitution establishes that: "matters not expressly assigned to the State by this Constitution may fall under the jurisdiction of the Self-governing Communities by virtue of their Statutes of Autonomy. Jurisdiction on matters not claimed by Statutes of Autonomy shall fall with the State, whose laws shall prevail, in case of conflict, over those of the Self-governing Communities regarding all matters in which exclusive jurisdiction has not been conferred upon the latter. State law shall in any case be suppletory of that of the Self-governing Communities." (section 149.3).

Finally, in order to limit the regulatory dispersion associated to the State of the Autonomies, the Constitution empowers the Central Government to "enact laws laying down the necessary principles for harmonizing the rulemaking provisions of the Self-governing Communities, even in
} 
Firstly, the Spanish political system is designed around a distribution of powers between central and regional legislatures, that have different legislative capacities and, therefore, it generates a framework for political and regulatory competition amongst SGC. However, the broad wording and (partial) overlap between some of the powers described in sections 148 (SGC's powers) and 149 (Central Government powers) of the Constitution introduces a degree of fuzziness in this division of powers between Central Government and SGC. Indeed, the exact wording of the powers -as they are assumed by SGC on their statutes- presents considerable variation, as different SGC use diverging terms to allude to the same powers and some of their definitions/descriptions enter in conflict with State powers.

Secondly, the foundation of SGC is also coupled with some financial autonomy and fund transfers by the Central state that may be increased across time $^{18}$. However, taxation was only transferred to the Basque Country and Navarra, following a historical privilege.

Finally, not all SGC have assumed the same powers over time, nor do they have exactly the same powers nowadays (GARCíA MILA \& MCGUIRE 2007). It is also true that a mere quantitative comparison of total powers transferred is misleading as they may lead to different levels of autonomy. In fact, the

the case of matters over which jurisdiction has been vested to the latter, where this is necessary in the general interest. It is incumbent upon the [Parliament], by overall majority of the members of each House [i.e. Congress and Senate], to evaluate this necessity" (section 150.3). However, to date, this power has never been used.

18 In this regard, the Constitution determines that "the Self-governing Communities shall enjoy financial autonomy for the development and exercise of their powers, in conformity with the principles of coordination with the State Treasury and solidarity among all Spaniards" (section 156.1). To achieve financial autonomy, "the resources of the Self-governing Communities shall consist of: a) Taxes wholly or partially made over to them by the State; surcharges on State taxes and other shares in State revenue. b) Their own taxes, rates and special levies. c) Transfers from an inter-territorial compensation fund and other allocations to be charged to the State Budget. d) Revenues accruing from their property and private law income. e) Interest from loan operations" (section 157.1).

More specifically, "an allocation may be made in the State Budget to the Self-governing Communities in proportion to the amount of State services and activities for which they have assumed responsibility and to guarantee a minimum level of basic public services throughout Spanish territory"; and, additionally, "with the aim of redressing inter-territorial economic imbalances and implementing the principle of solidarity, a compensation fund shall be set up for investment expenditure, the resources of which shall be distributed by the [Parliament] among the Self-governing Communities and provinces, as the case may be" (section 158). Therefore, the assumption of powers has usually been accompanied by transfer of funds from Central Government's budget to SGC's (MOLERO 2001; MORENO 2002) that may have also had an impact on the development of regional economies in Spain. 
Constitution allows for a dynamic evolution of the transfer of powers between the Central Government and each of the seventeen SGC: "the Self-governing Communities may, by amendment of their Statutes of Autonomy, progressively enlarge their powers" (section 148.2). Therefore, each SGC has evolved in a particular and different way from the rest -depending on a large number of factors, such as historical preconditions, social or political background, level of economic development, etc.- (see infra § 3.2. for a more detailed explanation of this process). These disparities in the assumption of powers have generated a more suitable framework for regulatory competition and economic impact analyses (LOPEZ LABORDA \& VALLÉS JiMÉNEZ 2006; GuAL, JódAR ROSELL \& Ruíz Posino 2006, ZaRATE \& VAlLÉS JimÉnEZ 2010; MARCos \& SANTALó 2010).

In exercise of their powers, SGCs may enact laws and adopt regulations, which are applicable to the agents and activities that take place in their territory. Occasionally conflicts may arise with the State or with neighbouring SGC regarding extraterritorial effects of SGC's rules ${ }^{19}$.

\subsection{EVolution OF DECENTRALISATION (1978 - 2010).}

As we have already mentioned, Spanish SGC have assumed different powers and, therefore, have reached diverse levels of self-government ${ }^{20}$. Moreover, not all of them exercise their legislative and regulatory powers with the same depth and intensity.

As regards the assumption of powers, we can see how the major transfers have taken place in subsequent waves (see Table 1). The first one occurred in the early 1980s when the system was being set up and the second one in the

\footnotetext{
${ }^{19}$ Moreover, the development of the State of the Autonomies in Spain generates an important debate about the appropriate schemes to finance the level of expense required by this two-tier system of public administration. In practice, however, the system is composed of three tiers, given that a local administration exists in addition to the abovementioned central and regional administrations. Nevertheless, the legislative and regulatory powers of municipal governments are much more limited than and largely conditioned by the regional and central regulations. Therefore, for the purposes of our study, we will focus on the existing relationship between central and regional administrations and, more specifically, on the legislative and regulatory activities of the SGC. This approach is consistent with that pursued by Spanish constitutional commentators, see for example AJA (2003).

${ }^{20}$ Table 1 summarises the transfer of powers to the different SGC during the period 1978-2010. A full table of transference of powers for the period 1978-2010 is available (in Spanish) at http://www9.mpt.es/documentacion/politica autonomica/traspasos/est traspasos/parrafo/00/do cument es/traspasos 1978 2010.pdf, visited 22.10.2010.
} 
mid 1990s. It is important to stress that the decentralisation process started from scratch in 1978, as the approval of the Constitution marked a switch from the centralist State set-up during the regime of the general Franco towards a decentralised system and the beginning of the new organizational model.

As mentioned before, the assumption of powers has not been homogeneous throughout the seventeen SGCs [GARCÍA MILÁ \& MCGUIRE (2007)]. Some of them assumed a large number of powers in the early 1980s, while others have achieved more extended autonomy only in the last 10 years. It is important to stress again that the quantity (in numerical terms) of powers assumed by each SGC is a rather rough measure. Not all of them are of the same relevance (in terms of specific powers assumed by SGC) but also -and that is the point we want to make here- because of the lack of a uniform system. First of all, it is impossible to know which is the total number of powers available: the list of powers contained in sections 148 and 149 of the Constitution is not exhaustive, and there may be other powers not mentioned that SGCs may assume according to section 149.3. Moreover, SGC's Statutes may phrase their powers in different terms and this gives any numerical comparison relative value. For that reason we will use the standard classification of powers used by the Spanish Ministry of Regional Policy and will classify all transfers of powers according to this scheme. We will not analyse the exact content of each of the powers ${ }^{21}$.

\footnotetext{
${ }^{21}$ Following the general approach of this study, we will neither try to weight the importance of different powers, nor elaborate our own estimate of the transfer. On the contrary, we will rely on data published by the Spanish Ministry for Territorial Policy as an independent, objective and authoritative source for this information.
} 
TABLE 1. SUMMARY OF THE TRANSFER OF POWERS BETWEEN THE

\section{Central Government AND the Self-Governing Communities (1978-2010)}

\begin{tabular}{|c|c|c|c|c|c|c|c|c|c|c|c|c|c|c|c|}
\hline & $\begin{array}{r}\text { Initial } \\
\text { Allocation }^{2} \\
\text { by Statute }\end{array}$ & 1978 & 1979 & 1980 & 1981 & 1982 & 1983 & 1984 & 1985 & 1986 & 1987 & 1988 & 1989 & 1990 & 1991 \\
\hline Andalucía & 89 & & 2 & & 8 & 10 & 28 & 22 & 10 & 5 & 2 & & & 7 & \\
\hline Aragón & 63 & & 3 & & 4 & 9 & 14 & 16 & 5 & 2 & 1 & & & & \\
\hline Asturias & 44 & & 1 & & 3 & 12 & 17 & 12 & 8 & 2 & 1 & & 3 & & \\
\hline Baleares Islands & 77 & & 2 & 1 & 3 & 9 & 14 & 13 & 6 & 3 & 1 & & & & \\
\hline Canarias & 36 & & 1 & & 3 & 4 & 21 & 15 & 17 & 5 & 1 & 1 & & 7 & \\
\hline Cantabria & 43 & & & & & 16 & 19 & 9 & 6 & 3 & & & & & \\
\hline Castilla-La Mancha & 89 & & 1 & & 3 & 11 & 20 & 11 & 8 & & 2 & & 3 & & \\
\hline Castilla y León & 43 & & & & 6 & 10 & 14 & 14 & 9 & 1 & 4 & & 3 & & \\
\hline Catalonia & 89 & 5 & 2 & 13 & 21 & 12 & 11 & 7 & 8 & 3 & 5 & & 6 & 1 & 5 \\
\hline Extremadura & 43 & & 1 & & 3 & 10 & 17 & 13 & 5 & 1 & & & 4 & & \\
\hline Galicia & 75 & & 2 & 1 & 1 & 20 & 18 & 17 & 13 & 3 & 4 & 2 & 8 & 1 & \\
\hline La Rioja & 32 & & & & & & 15 & 9 & 8 & 1 & 2 & & 2 & & \\
\hline Madrid & 35 & & & & & & 4 & 19 & 13 & 3 & & & 6 & & \\
\hline Murcia & 42 & & & 1 & 2 & 11 & 18 & 13 & 7 & 2 & 2 & & 2 & & 1 \\
\hline Navarra & 90 & & & & & & & & 16 & 16 & 1 & 3 & & 4 & \\
\hline Basque Country & 89 & 2 & 1 & 15 & 19 & 6 & 2 & & 21 & & 7 & & & & \\
\hline Valencia & 81 & & 3 & 1 & 3 & 14 & 21 & 14 & 19 & 4 & 5 & & 6 & & \\
\hline Total & 1060 & 7 & 19 & 32 & 79 & 154 & 253 & 204 & 179 & 54 & 38 & 6 & 43 & 20 & 6 \\
\hline
\end{tabular}

Source: Spanish Ministry of Regional Policy and own elaboration. Annex 1 reproduces a list of powers mentioned by 1978 Spanish Constitution. Note: "Initial allocation by Statute" refers to the number of powers initially assumed by the SGC in its corresponding Statute of Autonomy (date varied in each one, see list in Annex 1). An individual power-count was made for each SGC Statute within the list used by Spanish Ministry of Regional Policy to be consistent with information on power-transfers used afterwards.

${ }^{22}$ Initial allocation took place when each Statute of Autonomy was approved, not necessarily at the same time. See Annex 1 for the list of the Laws approving the Statutes of Autonomy of Spanish SGCs. 


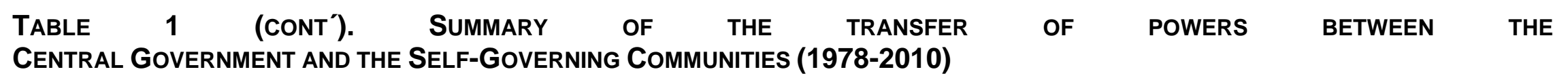

\begin{tabular}{|c|c|c|c|c|c|c|c|c|c|c|c|c|c|c|c|c|c|c|c|c|}
\hline & 1992 & 1993 & 1994 & 1995 & 1996 & 1997 & 1998 & 1999 & 2000 & 2001 & 2002 & 2003 & 2004 & 2005 & 2006 & 2007 & 2008 & 2009 & 2010 & TOTAL \\
\hline Andalucía & 4 & & & 10 & 1 & 3 & & 3 & & & & 1 & 11 & 8 & 3 & 5 & 8 & & 1 & 241 \\
\hline Aragón & 3 & 4 & 7 & 14 & 1 & 2 & 6 & 3 & & 1 & 1 & & & 1 & 3 & 2 & & 1 & 5 & 173 \\
\hline P. Asturias & & & 5 & 15 & & & & 11 & 4 & 1 & & & & 6 & 1 & & 2 & & & 148 \\
\hline Baleares Islands & 1 & 7 & & 19 & 5 & 3 & 2 & 7 & & 5 & & & & 3 & 2 & 3 & & 1 & & 187 \\
\hline Canarias & & 2 & 5 & 12 & 8 & & 7 & 2 & & 2 & & & 2 & & 3 & & & 1 & 3 & 159 \\
\hline Cantabria & & & & & 25 & & 6 & 3 & & 2 & & & & & 9 & 2 & 3 & & 2 & 148 \\
\hline Castilla-La Mancha & & 2 & & 14 & 5 & & 2 & 3 & & 2 & 2 & & & & 2 & & & & & 181 \\
\hline Castilla \& León & & 3 & 7 & 9 & 7 & & 4 & 5 & 3 & 2 & 2 & 3 & & & 1 & & & & 3 & 154 \\
\hline Catalonia & 4 & & 6 & 10 & 2 & 8 & 8 & 4 & 4 & 6 & 2 & 1 & 8 & 1 & 6 & 6 & 5 & 3 & 2 & 274 \\
\hline Extremadura & & 1 & 6 & 16 & & 3 & & 5 & & 4 & & 2 & & & 2 & & & & 2 & 139 \\
\hline Galicia & 2 & & 7 & 9 & 11 & 6 & 5 & 8 & & & 1 & & 3 & & 2 & 3 & 7 & & & 229 \\
\hline La Rioja & & & 8 & 3 & 8 & 2 & 5 & & 6 & 2 & 1 & & & & 2 & & & & & 107 \\
\hline Madrid & & 1 & 6 & 12 & 6 & 2 & 3 & 6 & 1 & 1 & 6 & 3 & 1 & & & & & & & 128 \\
\hline Murcia & & 2 & 7 & 19 & & 2 & 2 & 5 & & 5 & 2 & 1 & & & & & 6 & & & 153 \\
\hline Navarra & & & & & & 10 & & 7 & 2 & 1 & & & & & & & & & & 150 \\
\hline Basque Country & & & 9 & & 6 & & 2 & 1 & & & & & & & & & 2 & & & 182 \\
\hline Valencia & 2 & & & 7 & 7 & 3 & 4 & 6 & 5 & & 1 & & 1 & 2 & 1 & & & 1 & & 212 \\
\hline Total & 16 & 22 & 73 & 169 & 92 & 44 & 56 & 79 & 25 & 34 & 18 & 11 & 26 & 21 & 37 & 21 & 33 & 7 & 18 & 2965 \\
\hline
\end{tabular}

Source: Spanish Ministry of Regional Policy and own elaboration. Annex 1 reproduces a list of powers mentioned by 1978 Spanish Constitution.

Note: On 2010 we provide data accurate in 30.09.2010. 
The diverging degree of evolution of the decentralisation process can be easily identified throughout the period 1978-2010. For instance, in 1987 (at the end of the first decentralisation wave) the average number of powers transferred to SGC was 120 (60 assumed through the Statute of Autonomy and other 60 directly transferred by the State to the SGC); so at that time we could identify three groups of SGC according to the achieved level of autonomy:

a) high-level of transfer of powers (above average): Andalucía, Catalonia, Galicia, Basque Country and Valencia;

b) medium-level of transfer of powers (close to average): Aragón, Principality of Asturias, Baleares Islands, Canarias, Castilla-La Mancha, Castilla \& León, Extremadura, and Navarra; and

c) low-level of transfer of competencies (well below average): La Rioja, Murcia, Cantabria and Madrid.

In 1999 (at the end of the second decentralisation wave), the average number of powers assumed by the SGC had increased to 156 (through direct transfer from the State to the SGC) and there was a larger concentration of SGC in the mid-level group.

In 2005, the average number of transferred powers has increased to 165 and the distribution of SGC according to the level of autonomy assumed displays a similar concentration on the high-level of decentralization group. Nowadays, after a substantial transfer of powers to Andalucia, Catalonia and Murcia in 2008, the average number of powers assumed by SGC is 172 .

Therefore, as a general conclusion, we can derive that the decentralisation process is close to reaching the ceiling of the framework designed by the Constitution and the SGCs' Statutes of Autonomy (i.e., most of the powers that the SGC could assume have been assumed, and in order to transfer them additional powers reforms are required). This is one of the reasons why the Statutes of Autonomy of some of the major SGC have been or are being renegotiated lately (such as those for Catalonia, Valencia, Andalucía and Baleares Islands). 


\section{Measuring Regulatory Burden in the Spanish Decentralized} CONTEXT.

An objective measure of regulatory intensity that comparatively looks at each SGC from 1978 to 2008 is constructed: it is likely to be largely influenced by the variations in the powers assumed by each SGC. Another indicator of number of general rules per SGC and pages for general rules in SGC from 1988 to 2009 will be constructed (infra § 4.1). Moreover, in the later we will not only be using the total number of pages of Spanish regional Official journals, since we can also use a refined variable, including only the legal instruments and regulations adopted in each SGC through the number of pages of the SGC legislative chronological report published by the Spanish legal publisher Aranzadi 1988-2009 (infra § 4.2).

\subsection{First Measure: Number of Pages on the SGCs' official JOURnals} (1978-2008).

We will use the number of pages of the respective SGCs' Official journals in which all regional laws and rules are published as a proxy for SGC legislative and regulatory activism ${ }^{23}$.

We consider that the number of pages of SGCs' Official journals allows us to estimate regional regulatory intensity and of the burden that each SGC imposes on economic development and business activities in their respective territories.

We believe that quantity of legislation and regulatory activity can be a proxy for the interventionism of each SGC in economic development and business environment of their corresponding regions. In this regard, it is interesting to compare the evolution of the volume of the official publications of the SGC over time (see Table 2).

\footnotetext{
${ }^{23}$ It is important to stress that, apart from the Official Bulletin of the Central Government (Boletín Oficial del Estado), each SGC publishes its own Official Journal. Therefore, nowadays, there are eighteen Official Journals being published daily in Spain. And we should not forget that the Official Journal of the European Union also publishes daily an important number of legislative and regulatory norms that are also applicable to Spanish businesses. We consider that one can easily appreciate the important burden that such a dispersion of informative concerning the development of legislation and regulation is burdensome to businesses (specially to Small and Medium Enterprises, which constitute the largest block of the Spanish business network).
} 
Table 2. Number of pages yearly published in Official Journals of Self Governing Regions (1978-2008)

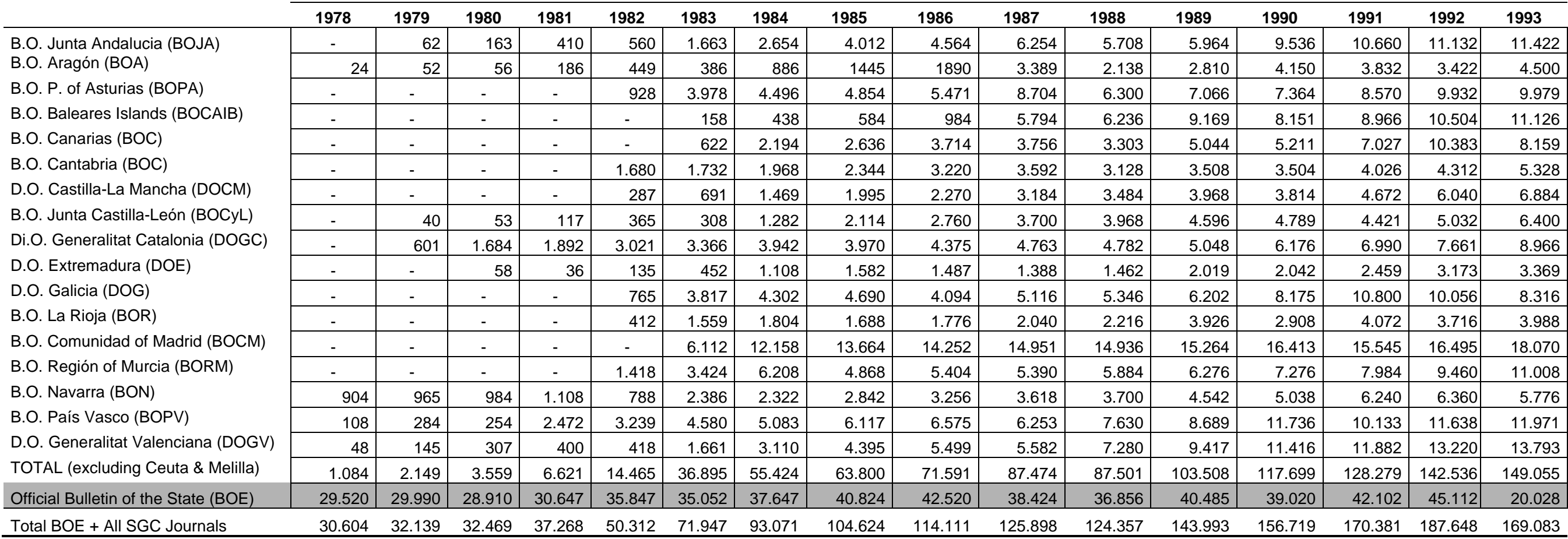

Note: See Annex 2 for an explanation of how the count was performed and additional information. 
Table 2 (cont'). Number of pages yearly published in Official Journals of Self Governing Regions (1978-2008)

\begin{tabular}{|c|c|c|c|c|c|c|c|c|c|c|c|c|c|c|c|}
\hline 1994 & 1995 & 1996 & 1997 & 1998 & 1999 & 2000 & 2001 & 2002 & 2003 & 2004 & 2005 & 2006 & 2007 & 2008 & \\
\hline 14.012 & 12.624 & 17.074 & 15.428 & 16.048 & 16.820 & 19.440 & 20.992 & 25.280 & 27.664 & 29.992 & 36.709 & 45.120 & 42.860 & 43.596 & B.O. Junta Andalucia (BOJA) \\
\hline 5.496 & 4295 & 5892 & 6.736 & 6.336 & 7.136 & 8.088 & 10.396 & 11.472 & 13.218 & 12.752 & 16.558 & 17.246 & 18.080 & 27.580 & B.O. Aragón (BOA) \\
\hline 11.904 & 13.856 & 13.951 & 16.396 & 16.053 & 14.192 & 15.264 & 16.326 & 16.672 & 16.272 & 19.168 & 23.100 & 24.732 & 24.668 & 28.760 & B.O. P. of Asturias (BOPA) \\
\hline 12.664 & 13.503 & 17.887 & 19.396 & 20.498 & 18.160 & 20.462 & 20.935 & 23.631 & 27.763 & 28.014 & 29.396 & 31.005 & 31.058 & 32.767 & B.O. Baleares Islands (BOCAIB) \\
\hline 10.203 & 12.667 & 13.246 & 15.504 & 16.027 & 17.444 & 19.487 & 19.832 & 22.636 & 20.840 & 22.788 & 24.792 & 30.168 & 28.384 & 26.771 & B.O. Canarias (BOC) \\
\hline 5.720 & 6.116 & 7.884 & 8.304 & 8.144 & 9.652 & 10.030 & 11.099 & 12.247 & 11.867 & 13.436 & 15.194 & 16.664 & 17.831 & 18.360 & B.O. Cantabria (BOC) \\
\hline 4.664 & 7.036 & 6.460 & 8.808 & 10.504 & 10.652 & 12.836 & 15.214 & 19.516 & 20.552 & 22.410 & 24.628 & 29.381 & 32.098 & 42.732 & D.O. Castilla-La Mancha (DOCM) \\
\hline 7.758 & 9.253 & 11.210 & 10.231 & 12.076 & 13.164 & 16.464 & 19.864 & 18.516 & 17.480 & 18.952 & 22.696 & 24.404 & 25.048 & 27.463 & B.O. Junta Castilla-León (BOCyL) \\
\hline 8.656 & 9.762 & 13.915 & 15.610 & 16.531 & 16.694 & 17.074 & 20.147 & 23.279 & 26.036 & 27.311 & 44.067 & 54.632 & 58.286 & 95.482 & Di.O. Generalitat Catalonia (DOGC) \\
\hline 5.384 & 5.592 & 6.409 & 8.903 & 9.605 & 10.252 & 12.919 & 12.966 & 15.768 & 15.567 & 15.832 & 18.408 & 21.807 & 20.132 & 35.481 & D.O. Extremadura (DOE) \\
\hline 8.664 & 9.854 & 12.092 & 12.640 & 13.948 & 15.432 & 17.148 & 16.676 & 18.132 & 16.524 & 18.700 & 20.588 & 19.100 & 20.544 & 23.428 & D.O. Galicia (DOG) \\
\hline 4.798 & 4.560 & 5.128 & 5.280 & 5.236 & 5.300 & 5.312 & 5.820 & 6.166 & 6.380 & 7.224 & 7.708 & 7.740 & 8.508 & 12.307 & B.O. La Rioja (BOR) \\
\hline 29.564 & 29.179 & 30.626 & 32.672 & 34.448 & 32.818 & 34.591 & 43.443 & 40.770 & 44.864 & 49.393 & 48.140 & 50.688 & 54.787 & 58.362 & B.O. Comunidad of Madrid (BOCM) \\
\hline 11.648 & 13.808 & 14.248 & 14.408 & 14.442 & 13.748 & 14.270 & 17.014 & 18.882 & 22.518 & 28.402 & 29.588 & 36.104 & 36.536 & 41.504 & B.O. Región of Murcia (BORM) \\
\hline 6.270 & 6.766 & 7.814 & 8.980 & 9.375 & 9.978 & 10.516 & 10.220 & 11.240 & 12.180 & 11.816 & 12.792 & 13.700 & 13.736 & 14.592 & B.O. Navarra (BON) \\
\hline 16.199 & 16.183 & 20.664 & 20.035 & 24.235 & 21.638 & 23.678 & 23.225 & 23.672 & 25.690 & 23.814 & 23.220 & 25.995 & 30.974 & 32.908 & B.O. País Vasco (BOPV) \\
\hline 15.537 & 17.644 & 15.309 & 20.349 & 21.117 & 21.398 & 24.467 & 28.328 & 33.942 & 31.602 & 34.496 & 41.872 & 42.000 & 48.001 & 93.925 & D.O. Generalitat Valenciana (DOGV) \\
\hline 179.141 & 192.698 & 219.809 & 239.680 & 254.623 & 254.478 & 282.046 & 312.497 & 341.821 & 357.017 & 384.500 & 439.456 & 490.486 & 511.531 & 656.018 & TOTAL (excluding Ceuta \& Melilla) \\
\hline 39.653 & 37.702 & 39.148 & 38.682 & 44.759 & 46.650 & 46.866 & 50.731 & 46.430 & 47.099 & 42.935 & 43.468 & 46.886 & 54.032 & 52.850 & Official Bulletin of the State (BOE) \\
\hline 218.794 & 230.400 & 258.957 & 278.362 & 299.382 & 301.128 & 328.912 & 363.228 & 388.251 & 404.116 & 427.435 & 482.924 & 537.372 & 565.563 & 708.868 & Total BOE + All SGC Journals \\
\hline
\end{tabular}

Note: See Annex 2 for an explanation of how the count was performed and additional information. 
It is also interesting to analyse the intensity of legislative and regulatory activity of the SGC through the ratio of published pages in the SGC Official journals per assumed power. As it could be expected, the average number of pages published in the SGCs' Official journals per (assumed) power has constantly increased and has nearly been multiplied by ten times in the period 1978 - 2008 (see Figure 1).

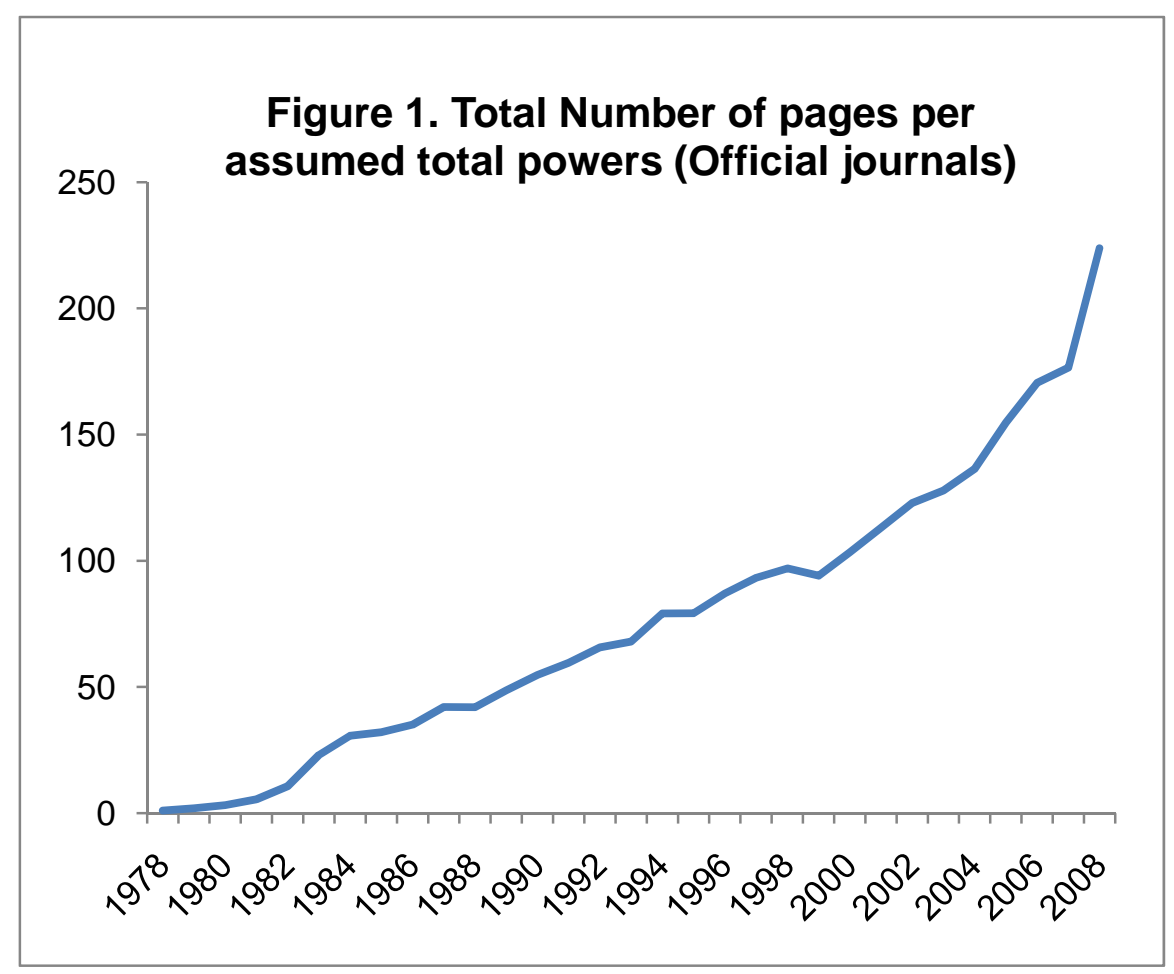

Therefore, as a general conclusion, we see how after the first thirty years of Spanish decentralisation, SGC regulate more both in absolute terms and in terms relative to the number of assumed competencies and of legislative or regulatory norms approved.

Interestingly enough, this increase of the SGC legislative and regulatory activity has not been followed by a proportional decrease of the legislative and regulatory activity of the Central Government -that has maintained a flat evolution, with very insignificant reductions in the number of published pages-. 


\subsection{SECOND MEASURE: DATA FROM ARANZADI REPORTER (1988-2009).}

The Aranzadi Chronological legislative collection, issued once a year, compiles all legislative and regulatory acts of a general application approved by each SGC for that given year. Since 1988, the Aranzadi report has been permanently published in a uniform format across SGC and over years, what makes it a very valuable tool for our purposes.

Therefore, we consider it a more refined proxy for regulatory intensity of SGC than official journals pages (although official journals' length tells us some additional information about SGC interventionism on economic activity).

We can carry out the same analysis performed above with SGCs' Official journals but based now on the Aranzadi Regional Legislative Collection data, and we will reach similar conclusions (for the period 1988-2009, which is the period covered by the Aranzadi SGC legislative compilation, see Table 3). 
Table 3. Number of pages published in Aranzadi Chronological Legislative Reporter (SGCs \& Central State) 1978-2009

\begin{tabular}{|c|c|c|c|c|c|c|c|c|c|c|c|c|c|c|c|c|c|}
\hline & 1978 & 1979 & 1980 & 1981 & 19821983 & 1984 & 1985 & 1986 & 1987 & 1988 & 1989 & 1990 & 1991 & 1992 & 1993 & 1994 & 1995 \\
\hline Andalucía & & & & & & & & & & 636 & 568 & 691 & 801 & 939 & 1.150 & 1.497 & 1.148 \\
\hline Aragón & & & & & & & & & & 237 & 330 & 270 & 472 & 462 & 458 & 608 & 701 \\
\hline Asturias & & & & & & & & & & 266 & 243 & 190 & 386 & 320 & 435 & 640 & 612 \\
\hline Baleares Islands & & & & & & & & & & 169 & 247 & 251 & 213 & 365 & 385 & 555 & 538 \\
\hline Canarias & & & & & & & & & & 271 & 386 & 485 & 749 & 536 & 819 & 1029 & 1.105 \\
\hline Cantabria & & & & & & & & & & 93 & 227 & 172 & 270 & 281 & 306 & 248 & 343 \\
\hline Castilla-La Mancha & & & & & & & & & & 163 & 162 & 215 & 317 & 314 & 323 & 333 & 463 \\
\hline Castilla \& León & & & & & & & & & & 314 & 437 & 523 & 455 & 509 & 519 & 856 & 674 \\
\hline Catalonia & & & & & & & & & & 635 & 901 & 1.010 & 896 & 1.241 & 1273 & 1415 & 1.651 \\
\hline Extremadura & & & & & & & & & & 120 & 219 & 255 & 242 & 347 & 281 & 392 & 390 \\
\hline Galicia & & & & & & & & & & 595 & 477 & 497 & 570 & 771 & 773 & 1054 & 849 \\
\hline La Rioja & & & & & & & & & & 228 & 151 & 301 & 215 & 396 & 421 & 534 & 531 \\
\hline Madrid & & & & & & & & & & 233 & 171 & 292 & 313 & 677 & 693 & 779 & 1.138 \\
\hline Murcia & & & & & & & & & & 248 & 258 & 341 & 289 & 520 & 450 & 670 & 915 \\
\hline Navarra & & & & & & & & & & 445 & 615 & 810 & 797 & 875 & 971 & 809 & 1.099 \\
\hline Basque Country & & & & & & & & & & 480 & 571 & 1.066 & 1.119 & 1316 & 1298 & 1434 & 1.259 \\
\hline Valencia & & & & & & & & & & 424 & 477 & 584 & 624 & 748 & 919 & 1266 & 1.235 \\
\hline Sum all SGC & & & & & 1.6332 .933 & 3.638 & 4.635 & 5.759 & 4.798 & 5.557 & 6.440 & 7.953 & 8.728 & 10.617 & 11.474 & 14.119 & 14.651 \\
\hline $\begin{array}{l}\text { Central State } \\
\text { National Reporter }\end{array}$ & 179 & 857 & .037 & 4.742 & 4.706 & 5.592 & 6.867 & 8.376 & 7.193 & 7550 & 9.396 & 8.849 & 9.518 & 835 & 14.014 & 0.615 & 10.496 \\
\hline
\end{tabular}

Note: It excludes chronological, alphabetical and topic indexes (see Annex 3 for an explanation of how the count was performed and additional information). 
Table 3 (cont'). Number of pages published in Aranzadi Legislative Reporter (SGCs \& Central State) 1978-2009

\begin{tabular}{|c|c|c|c|c|c|c|c|c|c|c|c|c|c|c|}
\hline 1996 & 1997 & 1998 & 1999 & 2000 & 2001 & 2002 & 2003 & 2004 & 2005 & 2006 & 2007 & 2008 & 2009 & \\
\hline 1.513 & 1.343 & 1.314 & 1.160 & 1.240 & 1.507 & 1.584 & 2.058 & 1.283 & 2.197 & 1.983 & 2.194 & 2.323 & 2.192 & Andalucía \\
\hline 712 & 701 & 726 & 834 & 839 & 1.233 & 1.334 & 1.113 & 915 & 1.110 & 1.374 & 1.152 & 1.393 & 1.585 & Aragón \\
\hline 490 & 703 & 690 & 654 & 692 & 1.121 & 1.408 & 934 & 882 & 1.120 & 1.113 & 1329 & 1.579 & 2.052 & Asturias \\
\hline 555 & 729 & 812 & 750 & 727 & 1.254 & 1.144 & 980 & 854 & 1.333 & 1.381 & 862 & 992 & 1.052 & Baleares Islands \\
\hline 754 & 796 & 920 & 986 & 851 & 800 & 960 & 1.244 & 1.020 & 1.124 & 1.491 & 1.186 & 1.138 & 1.315 & Canarias \\
\hline 480 & 433 & 601 & 593 & 572 & 775 & 817 & 817 & 928 & 934 & 1.232 & 1.206 & 1.178 & 1.066 & Cantabria \\
\hline 498 & 499 & 769 & 776 & 641 & 934 & 1.139 & 906 & 897 & 1.075 & 1.185 & 1.149 & 1.687 & 1.412 & Castilla-La Mancha \\
\hline 832 & 747 & 1.105 & 1.071 & 1308 & 1.369 & 1.754 & 1.954 & 1.476 & 1.643 & 1.669 & 1.884 & 1.667 & 2.727 & Castilla \& León \\
\hline 555 & 497 & 746 & 590 & 724 & 881 & 953 & 644 & 864 & 1.207 & 1.176 & 1.348 & 1.539 & 1.570 & Extremadura \\
\hline 1.103 & 1.205 & 1.280 & 1.204 & 1.495 & 1.199 & 1.230 & 1.136 & 1.143 & 1.255 & 1.227 & 1.538 & 2.160 & 1.698 & Galicia \\
\hline 506 & 394 & 678 & 537 & 862 & 713 & 801 & 820 & 855 & 1.098 & 1.096 & 1.091 & 1.160 & 1.319 & La Rioja \\
\hline 1.015 & 1.092 & 1.363 & 1543 & 1.426 & 1.638 & 1.731 & 1.696 & 1.151 & 1.702 & 1.739 & 1.304 & 1.561 & 1.565 & Madrid \\
\hline 711 & 831 & 885 & 668 & 781 & 1.180 & 1.559 & 1.252 & 1.193 & 1.405 & 1.512 & 1.489 & 1.463 & 1.611 & Murcia \\
\hline 1.096 & 1.149 & 1.293 & 1133 & 1.129 & 1.338 & 1.158 & 1.244 & 1.110 & 1.217 & 1.102 & 1.441 & 1.251 & 1.198 & Navarra \\
\hline 1.493 & 1.499 & 1.987 & 1312 & 1.728 & 1.498 & 1.293 & 1.545 & 1.217 & 1.711 & 1.552 & 1.649 & 1.927 & 1.367 & Basque Country \\
\hline 790 & 1.237 & 1.290 & 1134 & 1.194 & 1.332 & 1.406 & 1.351 & 1.348 & 1.610 & 1.817 & 1.810 & 1.773 & 1.932 & Valencia \\
\hline 11.123 & 8.607 & 10.398 & 8.350 & 8.238 & 9.959 & 9.324 & 9.153 & 8.454 & 7.759 & 9.202 & 8.705 & 10.176 & 11.235 & $\begin{array}{l}\text { Central State } \\
\text { National Reporter }\end{array}$ \\
\hline
\end{tabular}

Note: It ecludes chronological, alphabetical and topic indexes (see Annex 3 for an explanation of how the count was performed and additional information). 


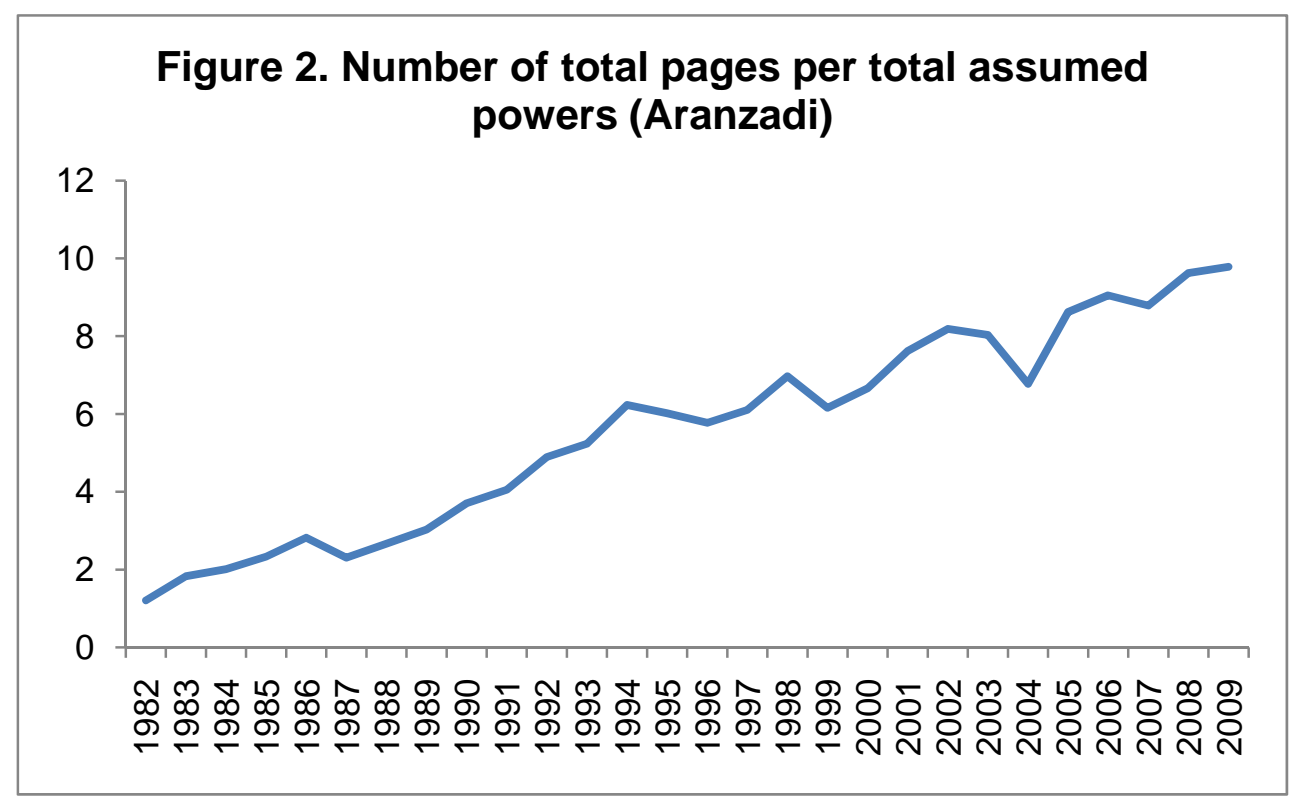

As we can see in Table 3, the number of total pages published by the Aranzadi Regional Legislative Reporter has been steeply increasing during the last twenty-two years. Moreover, the same conclusion holds in relation with the number of Aranzadi pages per total number of SGC assumed powers (looking at Table 1 supra, see Figure 2 supra).

Finally, as an additional measure of regulatory intensity we will look at the number of rules of general scope or efficacy adopted by each SGC. Undoubtedly, more rules always means a higher regulation intensity, although again this indicator can be criticized for still being too vague. Some of those laws or regulations will not be related to business or economic activities but only concern administrative or organization issues regarding each SGC. Nevertheless, it could generally be said that the number of general dispositions adopted by each SGC conveys a good image of how active it is in using rules as an instrument to exercise its powers.

In Table 4, we observe how in the period 1988-2009, the number of laws and other general norms passed by SGC displays a significant variance. But, maybe most worth noting, an important increasing tendency in the number of norms approved can be easily identified in all SGC. 
Table 4. Number of marginals accumulated (yearly), Aranzadi Chronological Legislative Reporter (1978-2009)

\begin{tabular}{|c|c|c|c|c|c|c|c|c|c|c|c|c|c|c|c|c|c|c|}
\hline & 1978 & 1979 & 1980 & 1981 & 1982 & 1983 & 1984 & 1985 & 1986 & 1987 & 1988 & 1989 & 1990 & 1991 & 1992 & 1993 & 1994 & 1995 \\
\hline Andalucía & & & & & & & & & & & 330 & 368 & 390 & 341 & 301 & 395 & 426 & 458 \\
\hline Aragón & & & & & & & & & & & 163 & 165 & 159 & 201 & 253 & 216 & 335 & 334 \\
\hline Asturias & & & & & & & & & & & 120 & 151 & 108 & 142 & 152 & 169 & 193 & 245 \\
\hline Baleares Islands & & & & & & & & & & & 168 & 173 & 160 & 160 & 195 & 230 & 272 & 247 \\
\hline Canarias & & & & & & & & & & & 182 & 263 & 230 & 290 & 268 & 316 & 331 & 335 \\
\hline Cantabria & & & & & & & & & & & 61 & 94 & 88 & 124 & 116 & 114 & 108 & 131 \\
\hline Castilla-La Mancha & & & & & & & & & & & 130 & 135 & 129 & 182 & 231 & 239 & 171 & 196 \\
\hline Castilla \& León & & & & & & & & & & & 226 & 299 & 261 & 305 & 319 & 347 & 416 & 371 \\
\hline Catalonia & & & & & & & & & & & 443 & 526 & 492 & 539 & 623 & 606 & 665 & 708 \\
\hline Extremadura & & & & & & & & & & & 113 & 159 & 170 & 179 & 190 & 194 & 251 & 229 \\
\hline Galicia & & & & & & & & & & & 249 & 267 & 281 & 285 & 323 & 334 & 369 & 351 \\
\hline La Rioja & & & & & & & & & & & 98 & 92 & 186 & 194 & 217 & 242 & 269 & 208 \\
\hline Madrid & & & & & & & & & & & 145 & 148 & 154 & 199 & 279 & 291 & 333 & 424 \\
\hline Murcia & & & & & & & & & & & 142 & 151 & 139 & 157 & 192 & 187 & 242 & 290 \\
\hline Navarra & & & & & & & & & & & 260 & 266 & 307 & 395 & 356 & 381 & 333 & 386 \\
\hline Basque Country & & & & & & & & & & & 256 & 256 & 414 & 381 & 426 & 537 & 574 & 420 \\
\hline Valencia & & & & & & & & & & & 314 & 269 & 278 & 342 & 310 & 371 & 416 & 412 \\
\hline Sum SGC & & & & & 1.335 & 2.302 & 3.131 & 3583 & 3.785 & 3.252 & 3.400 & 3.782 & 3.946 & 4.416 & 4.751 & 5.169 & 5.704 & 5.745 \\
\hline State National Reporter & 2.866 & 3.128 & 2.885 & 3.159 & 3.535 & 2.893 & 2.989 & 3106 & 3.935 & 2.751 & 2.652 & 2.818 & 2.751 & 3.068 & 2.883 & 3.646 & 3.604 & 3.556 \\
\hline
\end{tabular}

Note: Each marginal corresponds to one general norm adopted (be it an act, a regulation, an order, etc.). 
Table 4 (con't). Number of marginals accumulated (yearly), Aranzadi Chronological Legislative Reporter (1978-2009)

\begin{tabular}{|c|c|c|c|c|c|c|c|c|c|c|c|c|c|c|}
\hline 1996 & 1997 & 1998 & 1999 & 2000 & 2001 & 2002 & 2003 & 2004 & 2005 & 2006 & 2007 & 2008 & 2009 & \\
\hline 486 & 442 & 435 & 438 & 447 & 487 & 590 & 651 & 601 & 660 & 615 & 593 & 596 & 542 & Andalucía \\
\hline 223 & 218 & 213 & 244 & 274 & 369 & 345 & 333 & 309 & 335 & 375 & 429 & 475 & 554 & Asturias \\
\hline 335 & 386 & 336 & 351 & 271 & 305 & 361 & 435 & 360 & 351 & 447 & 519 & 499 & 446 & Canarias \\
\hline 220 & 184 & 209 & 224 & 211 & 264 & 312 & 286 & 295 & 354 & 352 & 339 & 350 & 311 & Cantabria \\
\hline 218 & 208 & 325 & 286 & 290 & 410 & 394 & 381 & 319 & 359 & 385 & 427 & 553 & 456 & Castilla-La Mancha \\
\hline 258 & 223 & 227 & 282 & 301 & 267 & 292 & 262 & 279 & 366 & 347 & 408 & 416 & 447 & Extremadura \\
\hline 408 & 445 & 423 & 429 & 382 & 389 & 386 & 393 & 402 & 399 & 401 & 408 & 541 & 442 & Galicia \\
\hline 264 & 185 & 263 & 253 & 281 & 241 & 265 & 268 & 264 & 267 & 310 & 347 & 344 & 324 & La Rioja \\
\hline 422 & 428 & 540 & 629 & 614 & 621 & 631 & 577 & 450 & 544 & 516 & 433 & 465 & 491 & Madrid \\
\hline 224 & 218 & 285 & 267 & 288 & 345 & 391 & 405 & 354 & 381 & 415 & 395 & 402 & 386 & Murcia \\
\hline
\end{tabular}

Note: Each marginal corresponds to one general norm adopted (be it an act, a regulation, an order, etc.). 
As a simple elaboration of some the previous information, we can calculate the number of pages per approved rule and we see how it has doubled during the period 1988-2009.

Additionally, as a further test of consistency of all the SGC regulatory indicators constructed Table 5 shows how not surprisingly all three regulatory indexes are significantly correlated ( $p$-value less than 0.0001). The last column also shows how all three indexes have a strong correlation with the number of powers transferred from the central government.

TABLE 5: CORRELATION MATRIX BETWEEN REGULATORY VARIABLES

\begin{tabular}{|c|c|c|c|c|}
\hline & (1) & (2) & (3) & (4) \\
\hline (1) Official Journal Pages & 1 & $0.27^{\star \star \star}$ & $0.42^{\star \star \star}$ & $0.62^{\star \star \star}$ \\
\hline (2) Aranzadi Marginals & & 1 & $0.92^{\star \star \star}$ & $0.73^{\star \star \star}$ \\
\hline (3) Aranzadi Pages & & & 1 & $0.73^{\star \star \star}$ \\
\hline (4) Powers transferred & & & & 1 \\
\hline
\end{tabular}

Where ${ }^{\star \star \star}$ represents that the correlations coefficient is significantly different than zero with a $p$ value less than 0.0001 .

Next we investigate to what degree the increase in all three regulatory indexes in 1978-2009 can be explained by the empowerment of Spanish regions during the same period. Table 6 displays the results of three OLS regressions in which the unit of observation is at the SGC-year level. Since the variables extracted from the Aranzadi Chronological Reporter (per SGC) only start in 1988 we run the three regressions using only information from that date onwards. The dependent variable is each of our regulatory indexes and the dependent variables are two: first, the accumulated total number of powers that the Spanish state has transferred to a given region in a given year to account by the fact that more empowered regions will legislate more; second the regional population that given year since more heavily populated regions might legislate a larger amount of pages ${ }^{24}$.

\footnotetext{
${ }^{24}$ In non-reported results we have also run more complex regressions in which the independent variables -apart from population and accumulated transferred competencies- were regional GDP and transferred competences to the square. However these two variables were either barely significant or we could not reject the hypothesis that their coefficients were equal to zero. This is why here we have just displayed the result of the simplest set of regressions.
} 
TABLE 6: REGRESSION OF REGULATORY INDEXES ON TRANSFERENCE OF POWERS

\begin{tabular}{|l|l|l|l|}
\hline & $\begin{array}{l}\text { Dep. Variable= Official } \\
\text { Journal Pages }\end{array}$ & $\begin{array}{l}\text { Dep. Variable= } \\
\text { Aranzadi Marginals }\end{array}$ & $\begin{array}{l}\text { Dep. Variable= } \\
\text { Aranzadi Pages }\end{array}$ \\
\hline Constant & $-43870^{\star \star \star}$ & $-556^{\star \star \star}$ & $-1016^{\star \star \star}$ \\
& $(8195)$ & $(96)$ & $(342)$ \\
\hline Transference of & $85.25^{\star \star \star}$ & $2.20^{\star \star \star}$ & $8.83^{\star \star \star}$ \\
powers & $(14.31)$ & $(0.16)$ & $(0.60)$ \\
\hline Population & $3208^{\star \star \star}$ & $41.27^{\star \star \star}$ & $47.41^{\star}$ \\
& $(645)$ & $(7.61)$ & $(27.13)$ \\
\hline $\mathrm{R}^{2}$ & 0.28 & 0.56 & 0.53 \\
\hline
\end{tabular}

Where ${ }^{\star * \star}$ represents that the correlations coefficient is significantly different than zero with a pvalue less than 0.0001 and the estimated standard error of the regressions coefficients are displayed below among parenthesis.

The last row of Table 6 shows how the variation of our regulatory indexes that can be explained by changes in population levels and regional empowerment is $56 \%$ at the most. This means that almost half of the variation in our regulation indexes is not accounted by the decentralization of the Spanish State and may be driven by a trend towards more regulation.

Using the estimated coefficients displayed in Table 6, we can estimate what should have been the value of our indexes for each region-year according to its level of empowerment and population. This allows us to compute the degree of deviation from real levels of our indexes. In percentage terms, we compute this difference between real and estimated regulatory index for each region-year and then we take the average across all years by region. The results are displayed in Table 7.

TABLE 7. \% DIFFERENCE BETWEEN REAL VALUE OF THE REGULATORY INDEX AND THE ESTIMATED VALUE ACCORDING TO LEVELS OF REGIONAL POPULATION AND REGIONAL EMPOWERMENT

\begin{tabular}{|l|l|l|l|}
\hline Region & $\begin{array}{l}\text { According to Official } \\
\text { Journal pages }\end{array}$ & $\begin{array}{l}\text { According to } \\
\text { Aranzadi Marginals }\end{array}$ & $\begin{array}{l}\text { According to } \\
\text { Aranzadi pages }\end{array}$ \\
\hline Andalucía & $-24.8 \%$ & $-12.6 \%$ & $-12.3 \%$ \\
\hline Aragón & $-44.3 \%$ & $-6.8 \%$ & $-18.7 \%$ \\
\hline P. Asturias & $+21 \%$ & $-17.4 \%$ & $-8.7 \%$ \\
\hline Balearic Islands & $+22.7 \%$ & $-18.3 \%$ & $-35.7 \%$ \\
\hline Canarias & $+3.2 \%$ & $+0.00 \%$ & $+2.4 \%$ \\
\hline Cantabria & $-4.7 \%$ & $-20.9 \%$ & $+18.7 \%$ \\
\hline Castilla-La Mancha & $-20.3 \%$ & $-14.85 \%$ & $-21.2 \%$ \\
\hline Castilla \& León & $-12.8 \%$. & $+29.0 \%$ & $+21.3 \%$ \\
\hline Catalonia & $-31.1 \%$ & $+18.6 \%$ & $+5.2 \%$ \\
\hline Extremadura & $-21.8 \%$ & $-11.3 \%$ & $-15.35 \%$ \\
\hline Galicia & $-36.8 \%$ & $-24.5 \%$ & $-28.08 \%$ \\
\hline La Rioja & $+40.6 \%$ & $+52.8 \%$ & $+66.6 \%$ \\
\hline Madrid & $+105 \%$ & $+29.23 \%$ & $+57.8 \%$ \\
\hline Murcia & $+28.7 \%$ & $-10.8 \%$ & $+5.7 \%$ \\
\hline Navarra & $-20.6 \%$ & $+28.5 \%$ & $+22.5 \%$ \\
\hline Basque Country & $+0.006 \%$ & $+8.1 \%$ & $+11.1 \%$ \\
\hline Valencia & $-1.1 \%$ & $-18.7 \%$ & $-20.3 \%$ \\
\hline
\end{tabular}




\section{Conclusion.}

This paper provides useful and descriptive tools and statistics of the regulatory sprawl of Spanish Self Governing Communities (SGC) since their inception thirty-two years ago. The time-series indicators constructed (19782009) take into account progressive transfers of powers by the central state and variations in the powers assumed by each SGC.

Our indicators are built around an objective and rough measure: the amount of legislation or regulation adopted by each SGC measured both by pages published in regional official journals and regional legislative reporters and rules adopted by each SGC. Through them we may look at SGCs' regulatory strategies (if there are any). Additionally, we cross-checked the consistency and correlation among all regulatory indicators and further performed a regression analysis of their relationship with progressive SGCs' empowerment over time. Further research should look at the impact disparate quantities of regulation by SGC may have had in economic performance. 


\section{Bibliographical RefERENCES:}

AJA, ELISEO (2003): El estado autonómico. Federalismo y hechos diferenciales. $2^{\mathrm{a}}$ Ed. Alianza Ensayo: Barcelona.

Alesina, Alberto; Silvia Ardagna; Giuseppe Nicoletti \& Fabio SCHIANTARELLI (2005): "Regulation and Investment," Journal of the European Economic Association, vol. 3(4), pages 791-825.

BLACK, RYAN C. \& JAMES F. SPRIggs II (2010): "An Empirical Analysis of the Trends, Determinants, and Effects of the Length of Majority opinions of the U.S. Supreme Court", Working Paper (available at http://works.bepress.com/cgi/ viewcontent.cgi?article=1001...james spriggs, visited 22.10.2010).

CABRILlo, Francisco (dir.) (2008): Index of Economic Freedom in the Spanish Autonomous Regions, Madrid (available http://www.libertadeconomica.es/freedom eng.pdf, visited 22.10.2010).

CONWAY, PAUL; VÉRONIQUE JANOD \& GIUSEPPE NICOLETTI (2005): "Product Market Regulation in OECD Countries: 1998 to 2003", OECD, Economic Department Working Papers $\mathrm{n}^{\circ}$ 419, available at http://www.olis.oecd.org, visited 30.07.2010).

COOTER, ROBERT D. \& TOM GINSBURg (2004): "Leximetrics: Why the Same Laws are Longer in Some Countries than Others", Working Paper 64, American Law \& Economics Assoc. Annual Meetings, available at http://law.bepress.com/alea /14th/art64, visited 22.10.2010).

DAWSON, JOHN. W. (2002): "Measuring Federal Regulation in the U.S.: 1938-1999", WP, Appalachian State University.

DJANKoV, SimEON; CARAlEe MCLIESH \& RitA Ma RAMAlHo (2006): "Regulation and growth" Economics Letters, vol. 92(3), September, pages 395401.

Friedman, MILTON (2004): "Freedom's Friend", The Wall Street Journal, 11 june 2004, page A8.

García-Milá, Teresa \& THERESE J. McGuire (2007): "Fiscal Decentralization in Spain: An Asymmetric Transition to Democracy", in BIRD, RichaRd M. \& EBEL, Robert D. (eds.), Fiscal Fragmentation in Decentralized Countries: Subsidiarity, Solidarity and Asymmetry, Edward Elgar: Cheltenham (UK), pages 208-223.

GATUSSO, JAMES L. (2004): "Reining In the Regulators: How Does President Bush Measure Up?" in Backgrounder, $\mathrm{n}^{\circ}$ 1801, September 28 (available at http://www.heritage.org/Research/Regulation/ bq1801.cfm visited 22.10.2010).

GofF, BRIAN (1996): Regulation and Macroeconomic Performance, Kluwer Academic Publishers: Boston, (Mass.).

Gørgens, Tue, Martin Paldam \& Alan Wurth (2003): "How does public regulation affect growth?", University of Aarhus Department of Economics Working Papers, $\mathrm{n}^{\circ}$ 2003-14 (available at ftp://ftp.econ.au.dk/afn/wp/03/wp03 14.pdf, visited 22.10.2010).

Gual, Jordi, SANDRA Jódar Rosell \& Àlex RuIz Posino (2006): "El problema de la productividad en España: ¿Cuál es el papel de la regulación?", Documentos de Economía "La Caixa" $\mathrm{n}^{\circ} 1$, june (available at http://www.pdf.lacaixa.comunicacions.com/de/esp/de01 esp.pdf, visited 22.10.2010). 
JALILIAN, Hossein; Colin KIRKPATRICK \& DAVID PARKER (2007): "The Impact of Regulation on Economic Growth in Developing Countries: A Cross-Country Analysis", World Development, vol. 35/1, pages 87-103.

Joskow, PETER L. \& NANCY L. ROSE (1989): "The Effects of Economic Regulation", in Schmalensee Richard \& WILLING, RoBert D. (eds.), Handbook of Industrial Organization, vol. II, Elsevier: Amsterdam, pages 1449-1506.

Joskow, Peter L. \& Roger G. Noll (1981): "Regulation in Theory and Practice: An Overview", in Fromm, GARY, ed., Studies in Public Regulation, The MIT Press: Cambridge (Mass.), pages 1-78.

KaHn, Alfred E. (1988): The Economics of Regulation, The MIT Press: Cambridge (Mass.).

LANDES, William M. \& Richard A. Posner (2004): The Political Economy of Intellectual Property Law, AEI-Brookings Joint Center for Regulatory Studies: Washington, D.C.

Lele, Priya P. \& Siems, Mathias M. (2007): "Shareholder protection: A Leximetric Approach", Journal of Corporate Law Studies, vol. 7, part 1, pages 17-50.

López Laborda, Julio \& Jaime VAllés Giménez (2006): "Factores Explicativos de la actividad reguladora de las Comunidades Autónomas (19892001)", IEF, Papeles de Trabajo 9/06 (available at www.ief.es/Publicaciones /PapelesDeTrabajo/pt2006 09.pdf, visited 22.10.2010).

LOYAZA, NORMAN V., ANA Ma OVIEDO \& LUIS SERVÉN (2004): "Regulation and Macroeconomic Performance", World Bank WPS 3469, Sept.(available at http://wwwwds.worldbank.org/servlet/WDSContentServer/WDSP/IB/2005/02/07/ $00009034120050207082757 /$ Rendered/PDF/wps3469.pdf, $\quad$ visited 22.10.2010).

MARCOS, Francisco \& JuAn SANTALó (2010): «Regulation, Productivity and Innovation», WP-IE Business School, 10/04 (available at http://ssrn.com/ abstract $=948457$, visited 22.10.2010).

MOLERO, JUAN CARLOS (2001): "Analysis of Decentralization of Public Spending in Spain", Public Finance and Management, vol. 1(4), pages 500-556 (available at http://mpra.ub.uni-muenchen.de/8056/1/MPRA paper 8056.pdf, visited 22.10.2010).

MoRENO, LUIS (2002): "Decentralization in Spain", Regional Studies 36/4, June, pages 399-408 (available at www.ipp.csic.es/doctrab2/dt-0115.pdf, visited 22.10.2010).

Nicoletti, Giuseppe \& Frederic L. Pryor (2006): "Subjective and objective measures of governmental regulations in OECD nations" Journal of Economic Behaviour \& Organization, vol. 59/3, March, pages 433-449.

Nicoletti GiusepPe \& Stegano ScARPETTA (2003): "Regulation, productivity and growth: OECD evidence," Economic Policy, vol. 18(36), pages 9-72.

Ogus, Anthony (1994): Regulation. Legal Form and Economic Theory, Clarendon Press: Oxford.

PÉrez DíAz, Victor M. (1993) The Return of Civil Society. The emergence of Democratic Spain, Harvard University Press: Cambridge (Mass.).

Pricewaterhousecoopers-World BANK (2006), Paying Taxes. The global Picture. November 2006 (available at ¡Error! Referencia de hipervínculo no válida., visited 22.10.2010). 
PRYOR, FREDERIC L. (2002) "Quantitative notes on the extent of governmental regulations in various OECD nations", International Journal of Industrial Organization 20/5, 693-714.

ROSELL LASTORTRAS, JUAN (2006) "La regulación: su cuantía y su coste", Actualidad Jurídica Uría Menéndez, $\mathrm{n}^{\circ}$ 14, pages 7-12 (available at ¡Error! Referencia de hipervínculo no válida., visited 22.10.2010).

ROSENTHAL, HOWARD \& ERIK VOETEN (2007): "Measuring Legal Systems", Journal of Comparative Economics, vol. 35, pages 711-28.

SANTAMARÍA PASTOR, JUAN ALFONSO (2004) "La Administración como poder regulador", en Estudios para la reforma de la Administración Pública, INAP: Madrid 2004, pages 375-445.

SChuCK, Peter H. \& E. Donald ElLIOTt (1990) "To the Chevron Station: An Empirical Study of Federal Administrative Law", Duke Law Journal, vol. 1990, pages 984-1077.

Siems, MATHIAS M. (2008): "Shareholder protection around the world (Leximetric II)", Delaware Journal of Corporate Law, vol. 33, pages 112-147.

VAllés JimÉmenez, Jaime \& ANABEL ZÁrate MARCo (2006) "Reflexiones en torno al debate del impacto económico de la regulación y los procesos institucionales para su reforma", Tribuna de Economía ICE, no 829, pages 205233 (available at http://www.revistasice.com/Estudios/Documen/ice 1829/ICE8290203.PDF, visited 22.10.2010).

VoIGT, Stefan (2009) "How (Not) to Measure Institutions", MAGKS Papers on Economics 2009, $n^{\circ} 37$, Philipps-Universität Marburg, Faculty of Business Administration and Economics, Department of Economics (available at http://www.uni-marburg.de/fb02/makro/forschung/magkspapers/37-

2009 voigt.pdf, visited 22.10.2010).

WOODRUFF, CHRISTOPHER (2006): "Measuring Institutions", in ROSEACKERMAN, SUSAN, ed., International Handbook on the Economics of Corruption, Willinston: Edward Elgar, pages 105-124.

Zárate Marco, Anabel \& Jaime Vallés Jiménez (2010): "The cost of regulation in a decentralized context: the case of the Spanish regions", European Journal of Law and Economics, forthcoming (available at http://springerlink.com/content/100264/?Content+Status=Accepted, visited 22.10.2010). 


\section{ANNEX 1: CONSTITUTIONAL FRAMEWORK FOR THE DISTRIBUTION OF POWERS BETWEEN THE CENTRAL GOVERNMENT AND THE SELF- GOVERNING COMMUNITIES}

Section 148: 1. The Self-governing Communities may assume powers over the following matters:

1. Organization of their institutions of self-government. 2. Changes in municipal boundaries within their territory and, in general, functions appertaining to the State Administration regarding local Corporations, whose transfer may be authorised by legislation on local government. 3. Town and country planning and housing. 4. Public works of interest to the Self-governing Community, within its own territory. 5. Railways and roads whose routes lie exclusively within the territory of the Self-governing Community and transport by the above means or by cable fulfilling the same conditions. 6 . Ports of haven, recreational ports and airports and, in general, those which are not engaged in commercial activities. 7. Agriculture and livestock raising, in accordance with general economic planning. 8. Woodlands and forestry. 9. Management of environmental protection.

10. Planning, construction and exploitation of hydraulic projects, canals and irrigation of interest to the Self-governing Community; mineral and thermal waters. 11. Inland water fishing, shellfish industry and fish-farming, hunting and river fishing. 12. Local fairs. 13. Promotion of economic development of the Self-governing Community within the objectives set by national economic policy. 14. Handicrafts. 15. Museums, libraries and music conservatories of interest to the Self-governing Community. 16. The Self-governing Community's monuments of interest. 17. The promotion of culture and research and, where applicable, the teaching of the Self-governing Community's language. 18. The promotion and planning of tourism within its territorial area. 19. The promotion of sports and the proper use of leisure. 20. Social assistance. 21. Health and hygiene. 22. The supervision and protection of its buildings and installations. Coordination and other powers relating to local police forces under the terms to be laid down by an organic act.

Section 149: 1. The State shall have exclusive competence over the following matters:

1. Regulation of basic conditions guaranteeing the equality of all Spaniards in the exercise of their rights and in the fulfilment of their constitutional duties. 2. Nationality, immigration, emigration, status of aliens, and right of asylum. 3. International relations. 4. Defence and the Armed Forces. 5. Administration of Justice. 6. Commercial, criminal and penitentiary legislation; procedural legislation, without prejudice to the necessary specialities in these fields arising from the peculiar features of the substantive law of the Self-governing Communities. 7. Labour legislation, without prejudice to its execution by bodies of the Self-governing Communities. 8. Civil legislation, without prejudice to the preservation, modification and development by the Self-governing Communities of their civil law, or special rights and traditional charters (fueros), whenever these exist. In any event, rules for the application and effectiveness of legal provisions, civil relations arising from the forms of marriage, keeping of records and drawing up to public instruments, bases of contractual liability, rules for resolving conflicts of law and determination of the sources of law in conformity, 
in this last case, with the rules of traditional charters (fueros) or special laws. 9. Legislation on copyright and industrial property. 10. Customs and tariff regulations; foreign trade. 11. Monetary system: foreign currency, exchange and convertibility; bases for the regulations concerning credit, banking and insurance. 12. Legislation on weights and measures and determination of the official time. 13. Basic rules and coordination of general economic planning. 14. General financial affairs and State Debt. 15. Promotion and general coordination of scientific and technical research. 16. External health measures; basic conditions and general coordination of health matters; legislation on pharmaceutical products. 17. Basic legislation and financial system of Social Security, without prejudice to implementation of its services by the Self-governing Communities. 18. Basic rules of the legal system of Public Administrations and the status of their officials which shall, in any case, guarantee that all persons under said administrations will receive equal treatment; the common administrative procedure, without prejudice to the special features of the Self-governing Communities' own organizations; legislation on compulsory expropriation; basic legislation on contracts and administrative concessions and the system of liability of all Public Administrations. 19. Sea fishing, without prejudice to the powers which, in regulations governing this sector, may be vested to the Self-governing Communities. 20. Merchant navy and registering of ships; lighting of coasts and signals at sea; general interest ports; general-interest airports; control of the air space, air traffic and transport; meteorological services and aircraft registration. 21. Railways and land transport crossing through the territory of more than one Self-governing Community; general system of communications; motor vehicle traffic; Post Office services and telecommunications; air and underwater cables and radio communications. 22. Legislation, regulation and concession of hydraulic resources and development where the water-streams flow through more than one Self-governing Community, and authorization for hydro-electrical power plants whenever their operation affects other Communities or the lines of energy transportation are extended over other Communities. 23. Basic legislation on environmental protection, without prejudice to powers of the Selfgoverning Communities to take additional protective measures; basic legislation on woodlands, forestry and cattle trails. 24. Public works of general benefit or whose execution affects more than one Self-governing Community. 25. Basic regulation of mining and energy. 26. Manufacturing, sale, possession and use of arms and explosives. 27. Basic rules relating to organization of the press, radio and television and, in general, all mass-communications media without prejudice to powers vested in the Self-governing Communities for their development and implementation. 28. Protection of Spain's cultural and artistic heritage and national monuments against exportation and spoliation; museums, libraries, and archives belonging to the State, without prejudice to their management by the Self-governing Communities. 29. Public safety, without prejudice to the possibility of Self-governing Communities creating police forces, as provided for in their respective Statutes of Autonomy and within the framework to be laid down by an organic act. 30. Regulation of the requirements for obtention, issuance and standardization of academic degrees and professional qualifications and basic rules for implementation of section 27 of the Constitution, in order to guarantee the fulfilment of the duties of public 
authorities in this matter. 31. Statistics for State purposes. 32. Authorization of popular consultations through the holding of referendums.

\section{Laws Approving the Statutes of Autonomy of the Spanish SGC}

Andalucía

LO 6/1981, of 30 december (BOE 9, of 11 january 1982)

Aragón

last amendment LO 2/2007, of 19 march (BOE 68, of 20 march 2007)

Principality of Asturias LO 8/1982, of 10 august (BOE 195, of 16 august1982) last amendment LO 5/2007, of 20 april (BOE 97, of 23 april 2007)

Baleares Islands LO 7/1981 of 30 december (BOE 9, of 11 january 1982)

Canarias LO 2/1983, of 25 february (BOE 51, of 1 march 1983)

Cantabria last amendment LO 1/2007, of 28 february (BOE 52, of 1 march 2007) LO 10/1982, of 10 august (BOE 195, of 16 august 1982)

Castilla-La Mancha LO 8/1981, of 30 december(BOE 9, of 11 january 1982)

Castilla \& León LO 9/1982, of 10 august (BOE 195, of 16 august 1982) LO 4/1983, of 25 february (BOE 52, of 2 march 1983) last amendment LO 14/2007, 20 april (BOE

Cataluña LO 4/1979, of 18 december (BOE 306, of 22 decemeber 1979)

Extremadura last amendment LO 6/2006, of 19 july (BOE 172, pf 20 july 2006)

Galicia LO 1/1983, of 25 february (BOE 49, of 26 february 1983) pending amendment in Congress (presented on 28 september 2009).

La Rioja LO 1/1981, of 6 april (BOE 101, of 28 march 1981)

Madrid LO 3/1982, of 9 june (BOE 146, of 19 march 1982)

Murcia LO 3/1983, of 25 february (BOE 51, of 1 march 1983)

Navarra LO 4/1982, of 9 june (BOE 146, 19 june 1982) LO 13/1982, of 10 august, of reintegration and improvement of autonomy conditions of Navarre (BOE 195, of 16 august 1982)

Vasque Country LO 3/1979, of 18 december (BOE 306, of 22 december 1979) Comunidad Valenciana LO 5/1982, of 1 july (BOE 164, of 10 july 1982) last amendment LO 1/2006, of 10 april (BOE 86, 11 march 2006) 


\section{ANNEX 2: COMPLEMENTARY INFORMATION ON THE DATA EXTRACTED FROM COUNTING SGC JOURNALS}

The SGC regulatory intensity indicator based on regional official journals (supra $\S$ 4.1) was constructed through a page-count of SGC official gazettes per natural year. The digital copies of the journals were used when available; however, to certain extent, issues published before the nineties physical copies of the journals were used. Access to the Libraries at the Universidad Autónoma de Madrid and National Library made the counting possible.

A few SGC official journals number the their journals' pages consecutively in each following issue (like the national official gazette) from page 1 every year making the exercise easier. Others do it every month, so a month count was performed and all months added to get final annual score. Others do it every issue (day), so all issues had to be checked and summed up to reach a yearly measure. Generally, the same format is used by each SGC official publication over the time, so the measure per SGC is consistent.

In those cases in which official journals were page numbered consecutively (like the Central State Official Bulletin -Boletín Oficial del Estado- and the majority of SGC official journals) it was enough to look at the last issue published each year (generally, on the 30th or 31st of December), as it provided information concerning the total number of pages published per year.

In the cases in which each issue of official Journal was page numbered independently (as it happens in the Madrid Community and Catalonia from the beginning, Baleares Islands from 2005 and Andalucia from 2005), it was necessary to check one by one all the issues published each year and to calculate the accumulated number of pages resulted from summing up all the published issues.

However, in the case of Catalonia, there exists a publication in CD-ROM by the Entitat Autònoma del Diari Oficial i de Publicacions de la Generalitat de Catalunya that gathers all the published journals until 2001 and follows an unofficial page-numbering that we have used for the construction of our database.

Official Journals include a wide variety of information. Naturally, they publish general norms (laws and regulations that apply to citizens and firms). But they also publish information regarding appointments, resignations and other decisions regarding public officials. They also publish information concerning public procurement, judgments and other public notices (even announcements by private firms and citizens may be included).

Moreover, in the performance of the counting, supplementary issues that were published attached to ordinary or regular issues of the bulletin were not taken into account. Normally these supplementary issues contain information regarding municipal administrations and notices to individuals, so they add few information regarding regulatory activities by SGCS.

Neither have we included the extraordinary issues of official journals. There is not a uniform policy among SGCs' oficial journals regarding their publication, indeed some of the SGC journals do not publish extraordinary issues at all. In those cases in which they are published there is not a uniform criterion determining what contents belong to them. Therefore, we have opted for excluding them from the database, that only includes ordinary issues of the oficial bulletin. 
On the other hand, as supplements and extraordinary issues kept independent page numbering, naturally they were automatically excluded from the total number of pages published as it appeared in the last issue of the year for those SGC page numbered them consecutively. In some isolated cases it is possible that some supplement or special number of the oficial Journal was numbered consecutively instead of being page-numbered independently, but these are rather uncommon and random cases, and for that reason we have not made any specific adjustment to face these errors in our database. For those SGC that page-number independently each issue of Journal, supplements and extraordinary issues have not been counted,

Finally, from 2008 onwards some SGC (Principality of Asturias, Murcia) have opted for an online digital publication system in which every norm of the journal is paged independently, this makes impossible to perform the page count exercise since then.

\section{ANNEX 3: COMPLEMENTARY INFORMATION ON THE DATABASE CONSTRUCTED FROM ARANZADI REGIONAL CHRONOLOGICAL LEGISLATIVE REPORTER}

The SGC regulatory intensity indicator based on Aranzadi Legislative Collection regional reported pages (supra § 4.2) was constructed through a page count of each SGC Aranzadi reporter. This Collection started in 1982 but the first few years (1982-1987) it compiled in one volume all SGC legislation and regulation and, thus, it was not valid for our purposes. After 1988, due to the volume reached by the published report, it was divided in 17 regional reports that segregate the data per SGC. For this reason, data from 1982 to 1987 are aggregated, whilst 1988-2009 they are disaggregated per SGC.

Therefore, a page-count exercise of the Aranzadi Regional reporter offers also a clear indicator of regulatory activity by SGC, capturing also the evolution of the administrative and organization activities by public administrations, including administration of justice and, in a lesser extent evolution of general economic activity (although the announcements by firms and citizens are a tiny part of the total publication volume of official journals).

Of course, despite having the same contents, the number of pages published per year by each SGC Aranzadi Reporter is a different measure than the number of pages published in the corresponding Official Journal. 